\title{
Parameter Optimization of Customized FDM 3D Printer Machine for Biocomposite Material [Sago/PMMA] Using $2^{\mathrm{k}}$ Fractional Factorial Design
}

\section{Optimasi Parameter Mesin 3D Printer FDM Customized Untuk Material Biokomposit [Sagu/PMMA] Menggunakan $2^{\mathrm{k}}$ Fractional Factorial Design}

\author{
Ibnu Abdul Rosid ${ }^{1}$, Alva Edy Tontowi ${ }^{1}$ \\ ${ }^{1}$ Teknik Industri, Fakultas Teknik dan Teknologi Informasi, Universitas Jenderal Achmad Yani Yogyakarta \\ Jl. Siliwangi, Banyuraden, Yogyakarta, 55293 \\ 2 Teknik Industri, Departemen Teknik Mesin dan Industri, Fakultas Teknik, Universitas Gadjah Mada \\ Jl. Grafika No. 2, Sleman, Yogyakarta, 55284 \\ email : ibnuabdulrosid@unjaya.ac.id \\ doi: https://doi.org/10.31315/opsi.v14i2.5352
}

Received: $12^{\text {th }}$ August 2021; Revised: $12^{\text {th }}$ December 2021; Accepted: $15^{\text {th }}$ December 2021;

Available online: $21^{\text {st }}$ December 2021; Published regularly: December 2021

\begin{abstract}
Bone fracture caused by various incident causes medical problems. Then bone restoration is required. Bone grafts can be used to solve this problem. One of the materials that can be used to produce bone graft is PMMA. PMMA requires to be combined with other materials to extend the solidification time. The material that can be used for bone graft material is sago starch. The main ingredient composition of Biocomposite [sago/PMMA] consists of sago: PMMA =1:1 (w/w). The composition of the addition of MMA is 10\% (v/w) of PMMA, this is to extend the curing time. Thus the material can be through from the chamber extruder to the nozzle. This research aims to obtain combinations of 3D Printer FDM Customized machine parameters for minimizing of error dimension. The $3 D$ Printer machine uses pneumatic system to push the material from the container to the chamber and used screw extruder to push the material out through the nozzle. The experimental design method used a $2^{k}$ fractional factorial design, with 3 parameters, 2 levels and 3 responses. The experimental results obtained that the layer height parameter has a significant influence on the $x$-dimensional error. The optimization results obtained a combination of parameters to get the smallest error dimensions, the print speed is $25 \mathrm{~mm} / \mathrm{s}$, the layer height is $2.93 \mathrm{~mm}$ and the fill density is $20 \%$. The results of optimization obtained that the $x$-dimensional error is 0.016, the $y$ dimensional error is 0.069 and the z-dimensional error is 0.4539 .
\end{abstract}

Keywords: bone graft, biocomposite, 3D Printer, optimization, parameter

\begin{abstract}
ABSTRAK
Kerusakan tulang yang diakibatkan oleh berbagai peristiwa menyebabkan permasalahan di bidang medis. Sehingga perlu dilakukan restorasi tulang. Bone graft dapat digunakan untuk menangani permasalahan tersebut. Salah satu material yang dapat digunakan untuk pembuatan bone graft adalah PMMA. PMMA perlu dikombinasikan dengan material lain untuk memperpanjang waktu solidifikasi. Adapun material yang dapat digunakan untuk paduan material bone graft adalah pati sagu. Komposisi main material pada Biokomposit [sagu/PMMA] terdiri dari sagu : PMMA =1:1 (w/w). Komposisi penambahan MMA sebesar 10\% $(\mathrm{v} / \mathrm{w})$ dari PMMA, hal tersebut untuk memperpanjang waktu curing. Sehingga material dapat dikeluarkan dari chamber melalui nozzle. Adapun penelitian ini bertujuan mendapatkan kombinasi parameter mesin 3D Printer FDM Customized untuk meminimalkan error dimensi printing. Mesin 3D Printer yang digunakan menggunakan pneumatik untuk mendorong material dari container menuju chamber dan screw ekstruder untuk mendorong material keluar melalui nozzle. Adapun metode design of experiment menggunakan $2^{k}$ fractional factorial design,
\end{abstract}


dengan 3 parameter, 2 level dan 3 respon. Hasil eksperimen didapatkan parameter layer height memiliki pengaruh yang signifikan terhadap error dimensi x. Pada hasil optimasi didapatkan kombinasi parameter untuk mendapatkan error dimensi terkecil, yaitu print speed sebesar $25 \mathrm{~mm} / \mathrm{s}$, layer height sebesar 2,93 mm dan fill density sebesar $20 \%$. Hasil running optimasi didapatkan error dimensi x sebesar 0,016, error dimensi y sebesar 0,069 dan error dimensi z sebesar 0,4539.

Kata Kunci: bone graft, biokomposit, 3D Printer, optimasi, parameter

\section{PENDAHULUAN}

Kondisi terjadinya kerusakan tulang (bone fracture) yang disebabkan karena berbagai kondisi memerlukan tindakan medis. Salah satu solusi untuk menyelesaikan permasalahan tersebut adalah restorasi kerusakan tulang menggunakan tulang buatan (bone graft) (Almy \& Tontowi, 2018; Deev, Drobyshev, Bozo, \& Isaev, 2015). Ada berbagai jenis bone graft, diantaranya autograft, allograft dan xenograf. Autograft merupakan graft yang diambil dari bagian tubuh pasien itu sendiri, allograft marupakan graft yang diambil dari manusia lain (same species), sedangkan xenograft merupakan graft yang diambil dari spesies mamalia. Berbagai jenis bone graft tersebut memiliki kelemahan, diantaranya risiko terjadinya infeksi, berpotensi merusak kesehatan jaringan tulang, biaya yang mahal, membutuhkan prosedur medis yang rumit (Puska, Aho, \& Vallittu, 2011) serta berpotensi menyebabkan komplikasi dari donor (Sonmez, Armagan, Ugurlar, \& Eren, 2017). Sehingga diperlukan alternatif untuk menangani kelemahan tersebut, salah satunya adalah penggunaan bone graft yang terbuat dari material buatan (sintetis) (Van Lieshout, Van Kralingen, El-Massoudi, Weinans, \& Patka, 2011). Adapun salah satu material sintetis yang dapat digunakan sebagai bone graft adalah Polymethyl Methacrylate (PMMA) (Almy \& Tontowi, 2018; Arora, Chan, Gupta, \& Diwan, 2013; Oryan, Alidadi, Bigham-Sadegh, \& Moshiri, 2018; Puska et al., 2011; Ranjan, Kumar, \& Kumar, 2017; Sekarjati \& Tontowi, 2018). PMMA merupakan biomaterial (Spasojevic et al., 2015) yang memiliki sifat termoplastik (Hashim, 2019).PMMA umum digunakan untuk keperluan restorasi gigi (Arora et al., 2013; Sheng, Shafee, Ariffin, \& Jaafar, 2018). Material PMMA dipasarkan dalam bentuk serbuk (powder) dan cair (liquid) (Ranjan et al., 2017). Material PMMA memiliki beberapa karakteristik berupa kekerasan (hardness) dan kemampuan tarik (tensile) yang baik, kaku (rigid) (Hashim, 2019), serta oil resistance (Pachamuthu \& Hatna, 2005). Terdapat berbagai kelemahan jika menggunakan material PMMA murni, diantaranya shrinkage (Sheng et al., 2018), sifat non-bioactive, kekuatan properti mekanik yang terbatas serta karakter mekanik yang kaku. Sehingga PMMA dapat dikombinasikan dengan material lain untuk mendapatkan karakteristik material baru (Almy \& Tontowi, 2018; Hashim, 2019; Oryan et al., 2018; Sheng et al., 2018).

Adapun teknologi yang dapat digunakan untuk membuat organ tiruan adalah 3D Printing (Almy \& Tontowi, 2018). Salah satu teknologi 3D Printer adalah Fused Deposition Modeling (FDM) (Surange \& Gharat, 2016), atau dapat disebut extrusion-based technique (Nematollahi, Xia, \& Sanjayan, 2017). 3D Printer FDM merupakan salah satu teknologi manufaktur yang populer digunakan di industri, serta dapat membuat benda dengan geometri yang kompleks dalam waktu yang relatif singkat (Nazan, Ramli, Alkahari, Sudin, \& Abdullah, 2017), biaya yang murah (Culmone, Smit, \& Breedveld, 2019; Pettalolo, Rosid, \& Tontowi, 2020), kemampuan mobilitas mesin yang mudah (Pettalolo et al., 2020), penggunaan yang mudah (Surange \& Gharat, 2016), kemampuan membuat bentuk yang kompleks dan dimensi produk yang besar (large-scale) (Nematollahi et al., 2017). 3D Printer FDM dapat dimodifikasi untuk mencetak material biokomposit berbentuk pasta biokomposit (Tontowi, Anggraeni, Saragih, Raharjo, \& Utami, 2017). Salah satu material paduan dengan komposisi PMMA yang dikembangkan untuk material bone graft adalah Biokomposit [Sagu/PMMA]. Material PMMA tersebut dikombinasikan dengan pati (starch) sagu, salah satu fungsi penambahan sagu untuk memperpanjang waktu pengerasan (curing time). Adapun kombinasi material tersebut ditambahkan Methyl Methacrylate (MMA) sebesar 50\% (v/w) dari berat PMMA (Putra \& Tontowi, 2019). Sedangkan properti mekanik dari material tersebut sebesar 3,337 Mpa untuk 
uji tarik dan kemampuan tekan sebesar 2,653 Mpa (Rosid, Putra, \& Tontowi, 2019). material tersebut dapat keluar melalui nozzle 3D Printer namun tidak secara secara kontinu, hal tersebut dikarenakan proses curing terjadi lebih cepat, sehingga menyebabkan material lebih cepat mengeras (fase solid) ketika material masih dalam proses ekstruksi di dalam chamber.

Sehingga diperlukan penelitian untuk menangani permasalahan tersebut dengan melakukan analisis dan uji coba printing material Biokomposit [Sagu/PMMA] menggunakan mesin 3D Printer FDM yang telah dimodifikasi (customized). Untuk menguatkan kebaruan, maka pada penelitian ini juga dikembangkan sistem ekstruksi untuk mesin 3D Printer FDM yang digunakan untuk material pasta Biokomposit [Sagu/PMMA].

Sehingga pada penelitian ini dilakukan perubahan komposisi penambahan MMA sebesar $10 \%(\mathrm{v} / \mathrm{w})$ dari berat PMMA. Pada penelitian ini juga dikembangkan sistem ekstruksi mesin 3D Printing FDM untuk material Biokomposit [Sagu/PMMA], sehingga mampu mengeluarkan material dari nozzle secara kontinu. Metode design of experiment yang digunakan adalah $2^{\mathrm{k}}$ fractional factorial design. Pada metode $2^{\mathrm{k}}$ factorial design dapat merepresentasikan kombinasi parameter, parameter tersebut dapat direduksi dengan menggunkan $2^{\mathrm{k}}$ fractional factorial design (Montgomery, 2009). Pada penelitian ini juga dikembangkan sistem ekstruksi mesin 3D Printer untuk material pasta Biokomposit [Sagu/PMMA].

\section{METODE}

\section{Sistem Ekstruksi}

Mesin 3D Printer yang digunakan adalah mesin 3D printer yang dikembangkan untuk material pasta dengan kemampuan bentuk dimensi produk sebesar $700 \mathrm{~mm}$ x $650 \mathrm{~mm}$ x $700 \mathrm{~mm}$ (gambar 1).

Sistem ekstrusi terdiri dari dari syringe yang digunakan untuk tempat material (container). Material pada container didorong dengan menggunakan pneumatik. Kemudian material disalurkan (transfer) menuju chamber ekstruder menggunakan saluran masuk extruder. Pada chamber ekstruder terdapat ulir (extruder screw) yang berfungsi untuk mendorong material keluar melalui nozzle ekstruder. Ulir tersebut dihubungkan dengan belt melalui pulley pada extruder screw dan pulley pada motor ekstruder. Adapun ulir pad screw extruder dibuat menggunakan polylactic acid (PLA), dengan shaft yang terbuat dari stainless steel. Sehingga material dapat terdorong keluar melalui nozzle. Adapun nozlle yang digunakan berdiameter 3,45 $\mathrm{mm}$. (gambar 2).

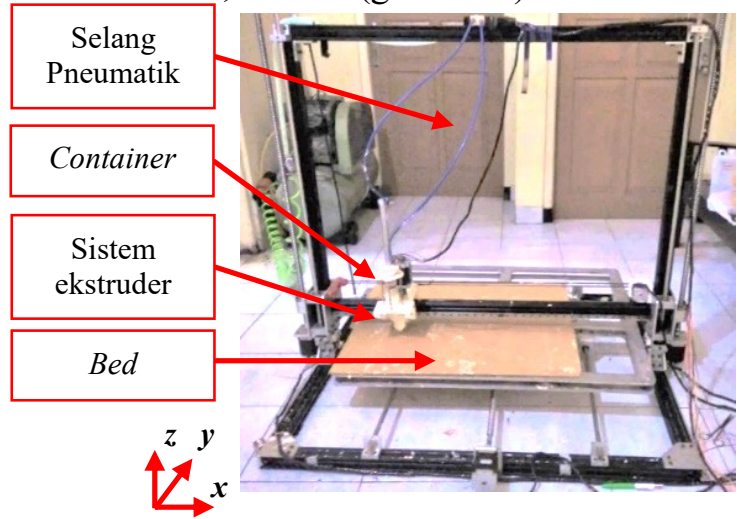

Gambar 1. Mesin 3D Printer FDM Customized

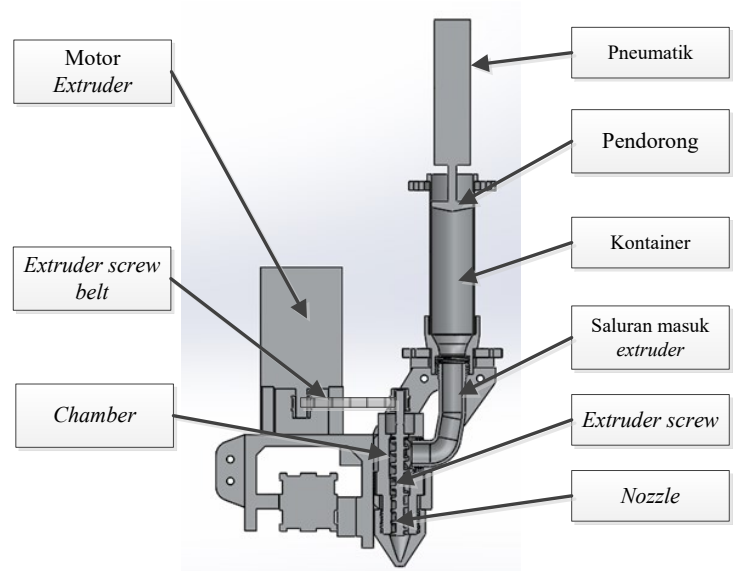

Gambar 2. Sistem ekstruksi

\section{Material Biokomposit}

Proses pembuatan material Biokomposit [Sagu/PMMA] dilakukan dengan mencampurkan starch sagu dan PMMA dengan komposisi 1:1 (w/w). Kemudian ditambahkan aquades sebesar $1: 1(\mathrm{v} / \mathrm{w})$ dari PMMA, asam cuka $\frac{1}{3}(\mathrm{v} / \mathrm{w})$ dari PMMA dan penambahan $\frac{1}{3}$ (v/w) dari PMMA. Kemudian material diaduk dengan menggunakan stirrer dengan kecepatan $300 \mathrm{rpm}$ selama 30 menit pada suhu ruang, setelah itu suhu dinaikkan hingga $50^{\circ} \mathrm{C}$ hingga material mengental. Kemudian ditambahkan MMA sebesar $10 \%$ (v/w) dan diaduk secara manual hingga cairan terserap (mixed) dengan material biokompsit. 


\section{Proses Printing}

Sebelum proses printing dilakukan, desain objek spesimen dan setting parameter dilakukan pada mesin 3D Printer. Objek printing berbentuk balok pejal dengan dimensi $200 \times 20$ x $6 \mathrm{~mm}$ (gambar 3) yang dibuat dengan menggunakan software CAD (Computer Aided Design) SolidWorks, file disimpan dalam bentuk STL (.stl). Kemudian dilakukan slicing dengan menggunakan software Repetier Host, sehingga didapatkan file berbentuk g-code (.gcode). File tersebut diinputkan ke dalam software Repetier-Host yang digunakan untuk kontrol program pada mesin 3D Printer FDM Customized. Adapun setting parameter menggunakan software Repetier-Host. Parameter yang ditentukan secara tetap diantaranya adalah layer thinckness sebesar travel speed sebesar $150 \mathrm{~mm} / \mathrm{s}$, perimeter speed sebesar $20 \mathrm{~mm} / \mathrm{s}$, temperatur sebesar $28^{\circ} \mathrm{C}$ (sesuai suhu ruang), Wall thickness sebesar 3.45 mm (sesuai dengan diameter nozzle).

Kemudian material Biokomposit [Sagu/PMMA] dimasukkan ke dalam container material, kemudian pendorong pneumatik dipasang pada container material. Screw extruder diputar sebesar 15-17 rpm dan pendorong ditekan dengan penumatik dengan tekanan 10-12 Psi. Setelah material keluar melalui nozzle, dilakukan proses printing. Kontrol running mesin 3D Printer dilakukan dengan menggunakan software Repetier-Host. Setelah spesimen selesai printing, dilakukan resting selama 24 jam dalam suhu ruang, kemudian dilakukan pengukuran spesimen.

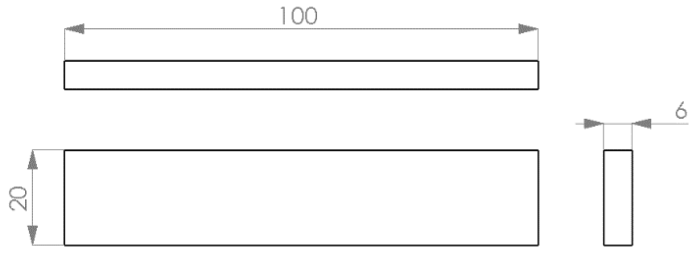

Gambar 3. Dimensi spesimen

\section{Design of Experiment}

Parameter pada penelitian terdiri dari 3 parameter yaitu print speed (PS), layer height (LH) dan fill density (FD) dengan 2 level. Pemilihan parameter didasarkan bahwa parameter tersebut berpengaruh langsung secara langsung pada hasil printing. Adapun level parameter ditentukan dengan pilot study. Penentuan level parameter print speed didapatkan dengan cara uji coba dengan mengatur print speed sebesar $5 \mathrm{~mm} / \mathrm{s}, 10 \mathrm{~mm} / \mathrm{s}$, $20 \mathrm{~mm} / \mathrm{s}, 25 \mathrm{~mm} / \mathrm{s}$ dan $30 \mathrm{~mm} / \mathrm{s}$. Bentuk spesimen yang mendekati bentuk desain CAD yaitu pada nilai print speed sebesar $20 \mathrm{~mm} / \mathrm{s}$ dan $25 \mathrm{~mm} / \mathrm{s}$. Pada penentuan level parameter fill density didapatkan dengan cara uji coba dengan mengatur fill density sebesar 20\%, 40\%, 60\%, $80 \%$ dan $100 \%$. Hasil uji coba didapatkan spesimen dengan bentuk mendekati bentuk desain CAD yaitu pada fill density sebesar $20 \%$ dan $40 \%$. Penentuan nilai layer height didapatkan dengan cara uji coba dengan mengatur layer height sebesar $1 \mathrm{~mm}, 2 \mathrm{~mm}$ dan $3 \mathrm{~mm}$ (disesuaikan dengan pembagi ketinggian spesimen), dengan hasil printing spesimen mendekati desain pada nilai layer height sebesar $2 \mathrm{~mm}$ dan $3 \mathrm{~mm}$. Adapun pola jalur printing (pattern path) menggunakan concentric, hal tersebut untuk menghindari terjadinya crossing jalur printing, sehingga tidak terjadi penumpukan material pada satu layer (gambar 4).

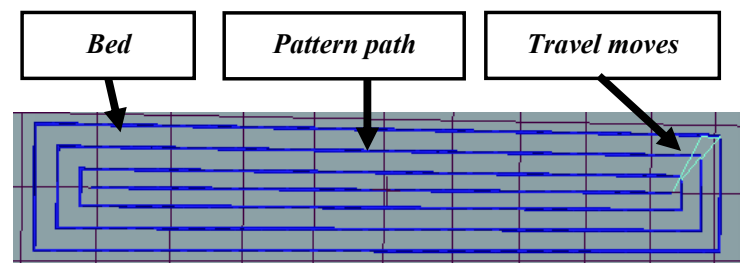

Gambar 4. Pattern Path

Respon yang digunakan yaitu error dimensi x, error dimensi y dan error dimensi z. pengukuran dilakukan dengan melakukan resting spesimen pasca printing selama 24 jam. Pengukuran menggunakan jangka sorong dengan ketelitian $0,05 \mathrm{~mm}$. Pengukuran untuk dimensi $\mathrm{x}$ sebanyak 3 titik pengukuran, pada dimensi y dan dimensi $\mathrm{z}$ sebanyak 5 titik pengukuran (gambar 5).

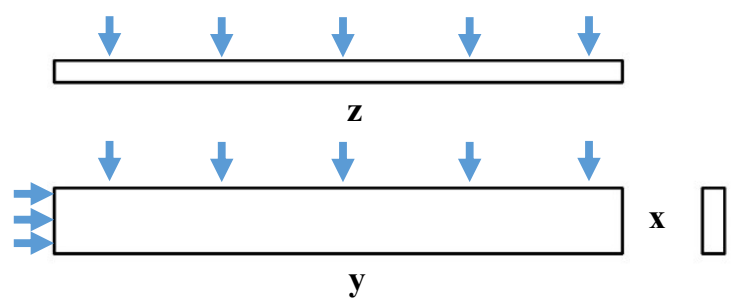

Gambar 5. Titik pengukuran

Perhitungan error dimensi menggunakan perhitungan dengan menghitung selisih antara dimensi desain $\left(D_{d}\right)$ dengan dimensi hasil 
printing $\left(\mathrm{D}_{\mathrm{p}}\right)$ yang dibandingkan dengan dimensi desain.

$$
\text { Error dimensi (\%) }=\left[\left[\frac{D_{p}-D_{d}}{D_{d}}\right] \times 100 \%\right]
$$

Analisis design of experiment menggunakan software Minitab. Pada generate menggunkan Minitab dengan replikasi 3 kali, didapatkan 12 run time. (tabel 1).

Tabel 1. Design of Experiment

\begin{tabular}{ccccccc}
\hline $\begin{array}{c}\text { Run } \\
\text { Time }\end{array}$ & PS & LH & FD & $\begin{array}{c}\text { PS } \\
(\mathrm{mm} / \mathrm{s})\end{array}$ & $\begin{array}{c}\text { LH } \\
(\mathrm{mm})\end{array}$ & $\begin{array}{c}\text { FD } \\
(\%)\end{array}$ \\
\hline 1 & -1 & -1 & +1 & 20 & 2 & 40 \\
2 & +1 & -1 & -1 & 25 & 2 & 20 \\
3 & -1 & +1 & -1 & 20 & 3 & 20 \\
4 & +1 & +1 & +1 & 25 & 3 & 40 \\
5 & -1 & -1 & +1 & 20 & 2 & 40 \\
6 & +1 & -1 & -1 & 25 & 2 & 20 \\
7 & -1 & +1 & -1 & 20 & 3 & 20 \\
8 & +1 & +1 & +1 & 25 & 3 & 40 \\
9 & -1 & -1 & +1 & 20 & 2 & 40 \\
10 & +1 & -1 & -1 & 25 & 2 & 20 \\
11 & -1 & +1 & -1 & 20 & 3 & 20 \\
12 & +1 & +1 & +1 & 25 & 3 & 40 \\
\hline
\end{tabular}

\section{HASIL DAN PEMBAHASAN}

Pada hasil proses printing dengan setting parameter sesuai dengan design of experiment, didapatkan dimensi spesimen yang beragam. Penyimpangan (error) maksimal sebesar 0,938 dan error minimum sebesar 0,0002 (tabel 2).

Tabel 2. Hasil pengukuran spesimen

\begin{tabular}{cccc}
\hline \multirow{2}{*}{$\begin{array}{c}\text { Run } \\
\text { time }\end{array}$} & \multicolumn{3}{c}{ Error dimensi } \\
\cline { 2 - 4 } & $\mathrm{x}$ & $\mathrm{y}$ & $\mathrm{z}$ \\
\hline 1 & 0,047 & 0,475 & 0,135 \\
\hline 2 & 0,034 & 0,328 & 0,212 \\
\hline 3 & 0,015 & 0,311 & 0,262 \\
\hline 4 & 0,016 & 0,109 & 0,357 \\
\hline 5 & 0,034 & 0,569 & 0,238 \\
\hline 6 & 0,053 & 0,657 & 0,283 \\
\hline 7 & 0,053 & 0,412 & 0,333 \\
\hline 8 & 0,006 & 0,336 & 0,370 \\
\hline 9 & 0,080 & 0,938 & 0,250 \\
\hline 10 & 0,0002 & 0,529 & 0,250 \\
\hline 11 & 0,012 & 0,327 & 0,352 \\
\hline 12 & 0,009 & 0,172 & 0,338 \\
\hline
\end{tabular}

Hasil analisis menggunakan Minitab didapatkan nilai koefisien determinasi $\left(\mathrm{R}^{2}\right)$ error dimensi x sebesar $71,68 \%$, error dimensi y sebesar 43,31\% dan error dimensi z sebesar $27,44 \%$.

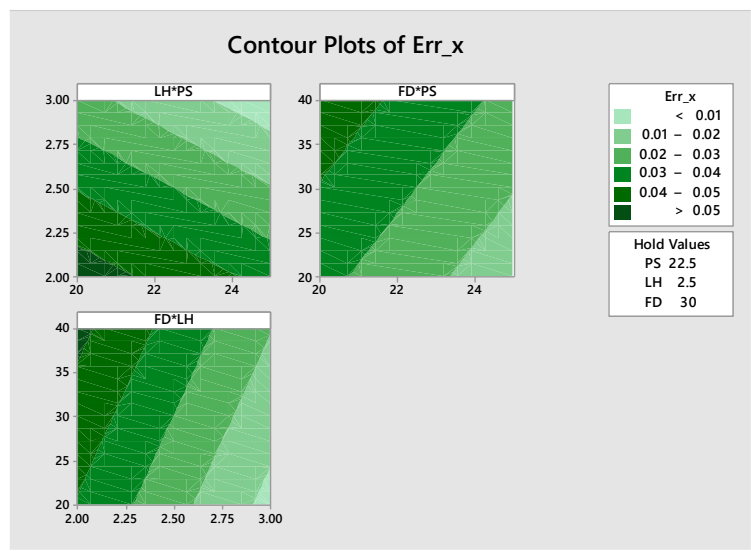

Gambar 6. Contour plots respon error dimensi x

Pada analisis contour plots untuk setiap variabel respon didapatkan pola kombinasi antar 2 parameter untuk mendapatkan error dimensi terkecil, yaitu pada respon error dimensi $\mathrm{x}$ dan $\mathrm{y}$, didapatkan berupa kombinasi layer height dan print speed semakin tinggi layer height dan semakin cepat print speed menghasilkan error dimensi semakin kecil. Sedangkan pada kombinasi fill density dan print speed semakin kecil fill density dan semakin cepat print speed $i$ menghasilkan error dimensi semakin kecil. pada kombinasi fill density dan layer height semakin kecil fill density dan semakin tinggi layer height menghasilkan error dimensi semakin kecil.

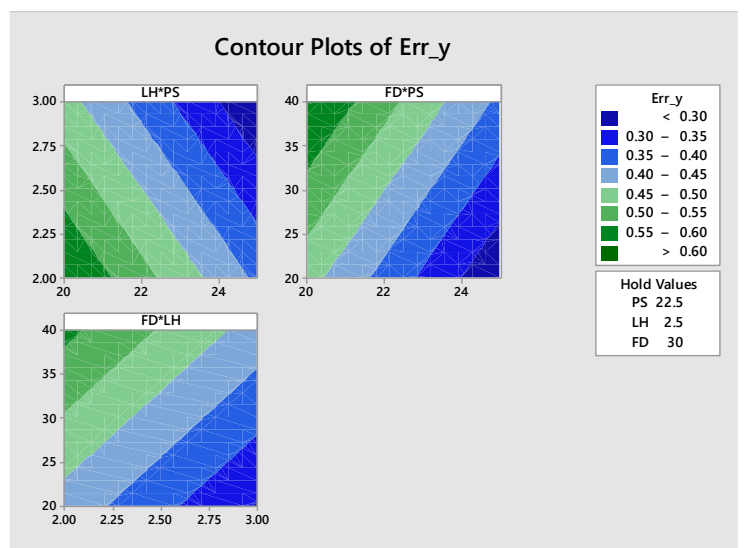

Gambar 7. Contour plots respon error dimensi y

Sedangkan pada respon error dimensi z yaitu semakin rendah layer height dan semakin cepat print speed menghasilkan error dimensi 
semakin kecil. Sedangkan pada kombinasi fill density dan print speed, semakin kecil fill density dan semakin cepat print speed menghasilkan error dimensi yang semakin kecil. pada kombinasi fill density dan layer height semakin kecil fill density dan semakin rendah layer height menghasilkan error dimensi semakin kecil.

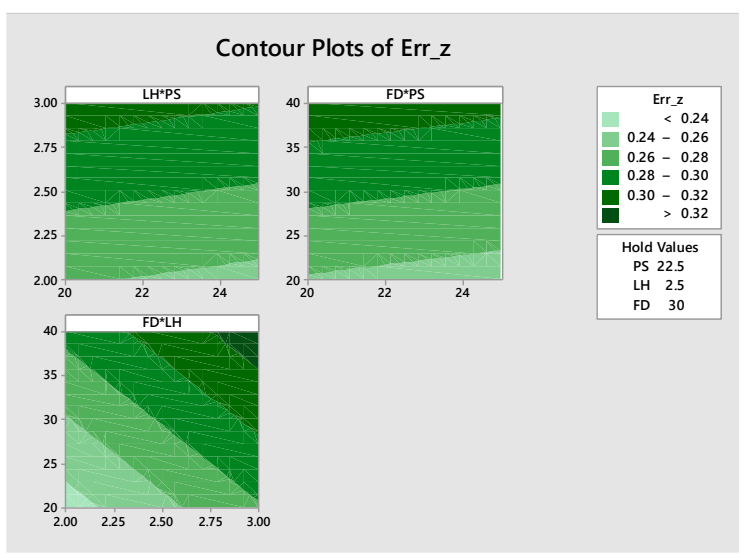

Gambar 8. Contour plots respon error dimensi z

Hasil pengolahan optimasi (optimizer) didapatkan kombinasi optimal untuk setiap parameter, yaitu print speed sebesar $25 \mathrm{~mm} / \mathrm{s}$, layer height sebesar 2,9293 $\mathrm{mm}$ dan fill density sebesar $20 \%$ (gambar 9). Adapun pada nilai parameter hasil optimasi nilai layer height dibulatkan menjadi $3 \mathrm{~mm}$, disesuaikan dengan kemampuan gerak mesin ke arah $\mathrm{z}$, yaitu $1 \mathrm{~mm}$ per step. Hasil dari optimasi kemudian dilakukan running pada mesin 3D Printer sesuai dengan nilai parameter yang didapatkan.

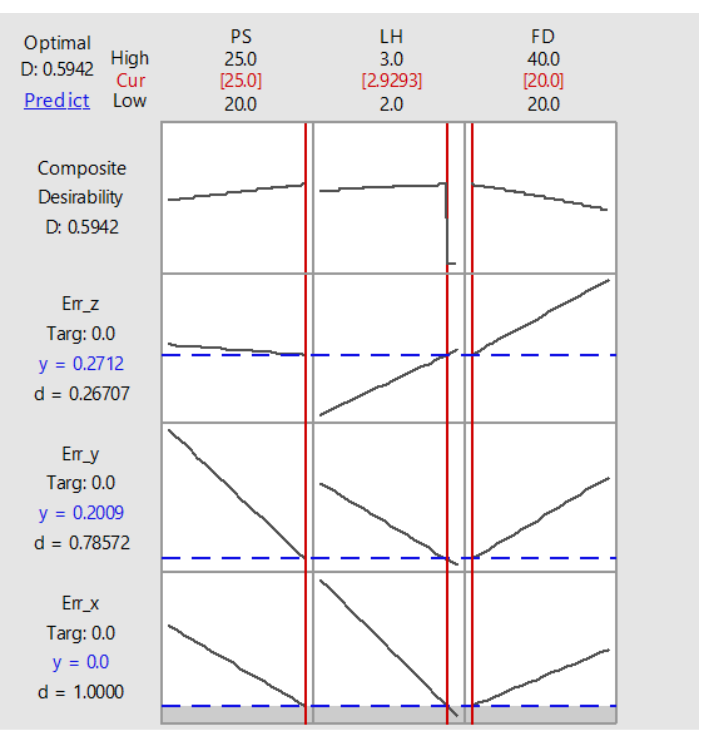

Gambar 9. Hasil optimasi
Hasil running dilakukan resting selama 24 jam. Setelah itu dilakukan pengukuran. Sehingga didapatkan dimensi spesimen hasil optimasi. Hasil rata-rata optimasi dibandingkan dengan rata-rata hasil eksperimen (tabel 3). Didapatkan bahwa hasil optimasi pada setiap variabel respon memiliki nilai error dimensi yang lebih kecil dibanding dengan nilai error dimensi eksperimen.

Tabel 3. Perbandingan dimensi spesimen

\begin{tabular}{cccc}
\hline & $\begin{array}{c}\text { Rata-rata } \\
\text { hasil } \\
\text { optimasi }\end{array}$ & $\begin{array}{c}\text { Rata-rata } \\
\text { hasil } \\
\text { eksperimen }\end{array}$ & Selisih \\
\hline $\begin{array}{c}\text { Error } \\
\text { dimensi x } \\
\text { Error }\end{array}$ & 0,0160 & 0,0300 & 0,0140 \\
$\begin{array}{c}\text { dimensi y } \\
\text { Error }\end{array}$ & 0,0690 & 0,4302 & 0,3612 \\
dimensi z & 0,4539 & 0,2817 & 0,1722 \\
\hline
\end{tabular}

Analisis visual dilakukan pada spesimen hasil printing. Pada hasil visual didapatkan terjadinya inkonsistensi bentuk pada sisi $\mathrm{x}, \mathrm{y}$ dan z (gambar 10).

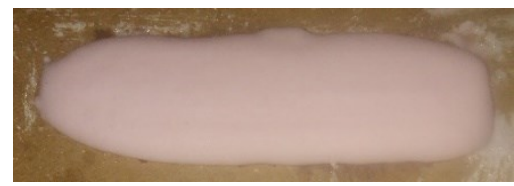

(a)



(b)



(c)

Gambar 10. Contoh spesimen hasil printing

Adapun pada sudut (corner) spesimen didapatkan bentuk sudut yang berbeda dengan desain CAD. Pada sudut tersebut tidak terbentuk siku $\left(90^{\circ}\right)$. Pada hasil pengamatan terbentuknya sudut yang tidak sesuai dengan desain CAD disebabkan karena putaran motor screw ekstruder yang tidak sesuai dengan kecepatan gerak nozzle $\left(\mathrm{V}_{\mathrm{n}}\right)$ (gambar 10), dimana putaran extruder yang konstan sedangkan gerak nozzle tidak melambat saat membentuk sudut (gambar 11). 


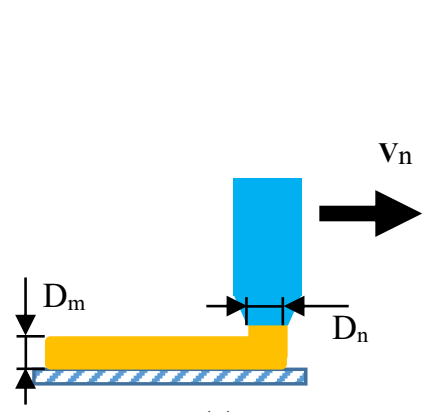

(a)

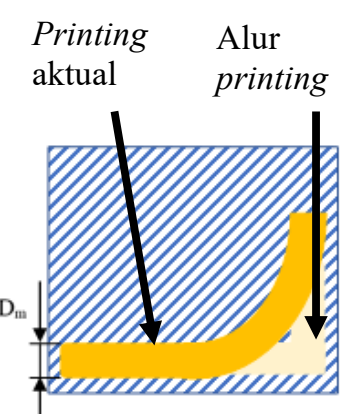

(b)

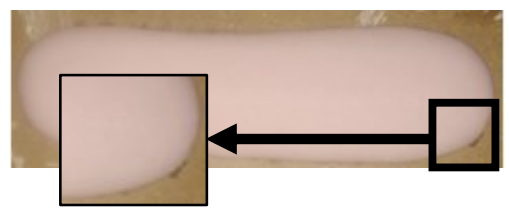

Sudut spesimen printing

(c)

Gambar 11. (a) skema printing tampak samping, (b) skema printing tampak atas dan (c) visual hasil printing

Pada pengamatan penyebab error dimensi $\mathrm{z}$, didapatkan hasil berupa terjadinya degradasi material $\left(\mathrm{Dm}_{\mathrm{x} / \mathrm{y}}\right)$, hal tersebut disebabkan karena material pada layer sebelumnya (pertama) memiliki viskositas yang masih rendah, sehingga layer berikutnya (kedua) tidak dapat terbentuk secara sempurna. Sehingga ketinggian terjadi penurunan dan dimensi pada arah $\mathrm{x}$ dan $\mathrm{y}$ bertambah (gambar 12).

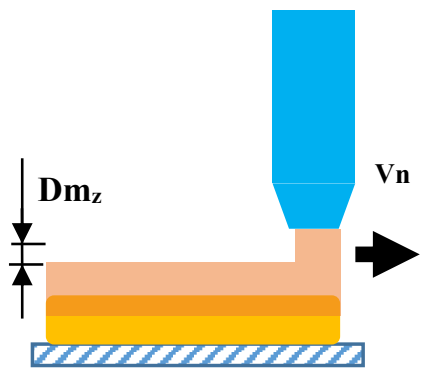

(a)

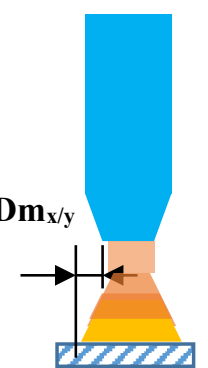

(b)
Gambar 12. Skema visualisasi printing

\section{KESIMPULAN}

Hasil printing material Biokomposit [Sagu/PMMA] dengan penambahan MMA sebesar $10 \quad \% \quad(\mathrm{v} / \mathrm{w})$ yang di printing menggunakan mesin 3D Printer FDM Customized didapatkan dimensi yang berbeda dengan dimensi pada desain CAD. Adapun ratarata error untuk dimensi $\mathrm{x}$ adalah 0,0300 ; error dimensi y sebesar 0,4302 dan error dimensi $\mathrm{z}$ sebesar 0,2817. Kombinasi parameter yang optimum untuk error dimensi terkecil yaitu print speed sebesar $25 \mathrm{~mm} / \mathrm{s}$, layer height sebesar 2,93 $\mathrm{mm}$ dan fill density sebesar 20\% dengan menghasilkan error dimensi x sebesar 0,0160; error dimensi y sebesar 0,0690 dan 0,4539 . Pada analisis visual didapatkan pada sudut (corner) spesimen tidak terbentuk siku sesuai dengan desain pada CAD, hal tersebut disebabkan setting kecepatan gerak nozzle dan putaran ekstruder yang tidak sesuai serta viskositas material yang rendah, sehingga material pada next layer terdegradasi ke arah $\mathrm{x}$ dan $\mathrm{y}$.

Adapun saran untuk penelitian selanjutnya untuk meminimalkan error dimensi adalah perlu dilakukan analisis dan uji coba printing dengan menambahkan parameter printing lainnya, pengembangan desain ekstruder agar proses ekstruksi lebih kontinu, serta pengembangan material pasta Biokomposit [Sagu/PMMA] lebih lanjut untuk mendapatkan properti material yang sesuai dengan sistem ekstruksi yang dikembangkan. Kemudian juga diperlukan penambahan kapasitas kontainer dan sistem ekstruksinya agar volume printing dapat lebih besar.

\section{UCAPAN TERIMA KASIH}

Penelitian dilakukan di Laboratorium Desain Produk dan Bioceramics Departemen Teknik Mesin dan Industri Fakultas Teknik Universitas Gadjah Mada. Serta terima kasih kepada Anggono Supriyambodo, A.Md. selaku Laboran Laboratorium Desain Produk dan Bioceramics.

\section{DAFTAR PUSTAKA}

Almy, R. D., \& Tontowi, A. E. (2018). The Effect of 3D Printing Machine Parameters in Extrusion Process of Biocomposite Materials (PMMA and HA) on Dimensional Accuracy. SINERGI, 22(2), 83-90.

Arora, M., Chan, E. K. S., Gupta, S., \& Diwan, A. D. (2013). Polymethylmethacrylate Bone Cements and Additives: A Review of the Literature. World Journal of Orthopedics, 4(2), 67-74.

Culmone, C., Smit, G., \& Breedveld, P. (2019). Additive Manufacturing of Medical Instruments: A state-of-the-art Review. 
Additive Manufacturing, 27, 461-473. Elsevier. Retrieved from https://doi.org/10.1016/j.addma.2019.03.0 15

Deev, R. V., Drobyshev, A. Y., Bozo, I. Y., \& Isaev, A. A. (2015). Ordinary and Activated Bone Grafts: Applied Classification and the Main Features. BioMed Research International, 2015. Hindawi Publishing Corporation.

Hashim, A. (2019). Recent Review on Polymethyl methacrylate (PMMA)Polystyrene (PS) Blend Doped with Nanoparticles For Modern Applications. Research Journal of Agriculture and Biological Sciences, (December), 2-9.

Van Lieshout, E. M. M., Van Kralingen, G. H., El-Massoudi, Y., Weinans, H., \& Patka, P. (2011). Microstructure and biomechanical characteristics of bone substitutes for trauma and orthopaedic surgery. $B M C$ Musculoskeletal Disorders, 12(1), 34. BioMed Central Ltd. Retrieved from http://www.biomedcentral.com/14712474/12/34

Montgomery, D. C. (2009). Introduction To Statistical Quality Control. (Sixth.). Missouri: Wiley.

Nazan, M. A., Ramli, F. R., Alkahari, M. R., Sudin, M. N., \& Abdullah, M. A. (2017). Process Parameter Optimization of 3D Printer Using Response Surface Method. Journal of Engineering and Applied Sciences, 12(7), 2291-2296.

Nematollahi, B., Xia, M., \& Sanjayan, J. (2017). Current progress of $3 \mathrm{D}$ concrete printing technologies. The 34th International Symposium on Automation and Robotics in Construction (pp. 260-267).

Oryan, A., Alidadi, S., Bigham-Sadegh, A., \& Moshiri, A. (2018). Healing potentials of Polymethylmethacrylate Bone Cement Combined with Platelet Gel in The Critical-sized Radial Bone Defect of Rats. PLoS ONE, 13(4), 1-17.

Pachamuthu, P., \& Hatna, S. (2005). Studies on Poly(methyl methacrylate) (PMMA) and Thermoplastic Polyurethane (TPU) Blends. Journal of Macromolecular Science - Pure and Applied Chemistry, 42(10), 1399-1407.

Pettalolo, A. N. Y., Rosid, I. A., \& Tontowi, A. E. (2020). Pengembangan Material
Reusable Concrete untuk 3DP Building. Conference SENATIK STT Adisutjipto Yogyakarta (Vol. 6, pp. 59-66).

Puska, M., Aho, A. J., \& Vallittu, P. (2011). Polymer composites for bone reconstruction. Advances in Composite Materials, 55-71.

Putra, I. R., \& Tontowi, A. E. (2019). Properti Mekanik Material [ Sagu / PMMA ] "3D Printable ." Seminar Nasional Inovasi dan Aplikasi Teknologi di Industri (pp. 320323).

Ranjan, R. K., Kumar, M., \& Kumar, R. (2017). Bone cement. International Journal of Orthopaedics Sciences, 3(4), 79-82.

Rosid, I. A., Putra, I. R., \& Tontowi, A. E. (2019). Mechanical properties of tensile and bending stregth analysis in biocomposite [Sagoo/PMMA] material. Seminar Nasional Teknologi Informasi dan Kedirgantaraan (Vol. V, pp. 507514). Yogyakarta.

Sekarjati, K. A., \& Tontowi, A. E. (2018). The composition of biocomposite [polymethyl methacrylate/ hydroxyapatite] as material for specimen with portabee kit machine. SINERGI, 22(3), 169-176.

Sheng, T. J., Shafee, M. F., Ariffin, Z., \& Jaafar, M. (2018). Review on Poly-methyl Methacrylate as Denture Base Materials. Malaysian Journal of Microscopy, 14(1), $1-16$.

Sonmez, M. M., Armagan, R., Ugurlar, M., \& Eren, T. (2017). Allografts versus Equine Xenografts in Calcaneal Fracture Repair. The Journal of Foot \& Ankle Surgery, 56, 510-513.

Spasojevic, P., Zrilic, M., Panic, V., Stamenkovic, D., Seslija, S., \& Velickovic, S. (2015). The Mechanical Properties of a Poly(methyl methacrylate) Denture Base Material Modified with Dimethyl Itaconate and Di-n-butyl Itaconate. International Journal of Polymer Science, 2015.

Surange, V. G., \& Gharat, P. V. (2016). 3D Printing Process Using Fused Deposition Modelling (FDM). International Research Journal of Enineering and Technology, 03(03), 1403-1406.

Tontowi, A. E., Anggraeni, D., Saragih, H. T., Raharjo, K. P. N., \& Utami, P. (2017). Experimental Study of 3D-Printable 
Opsi

Vol 14 No 2 December 2021

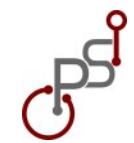

p-ISSN 1693-2102

e-ISSN 2686-2352

Biocomposite of [ HA / PMMA / Sericin ]

Materials. Advance Materials Letters, 8(8),

857-861. 